\title{
Effect of Different Doses of PMSG for Synchronisation of Estrus in Progesterone Primed Goats
}

\author{
K. Kavitha ${ }^{1 *}$, Cecilia Joseph ${ }^{1}$, T. Sarath ${ }^{2}$ and C. Pugazharasi ${ }^{3}$ \\ ${ }^{1}$ Department of Veterinary Gynaecology and Obstetrics, Madras Veterinary College, \\ Chennai, Tamil Nadu, India \\ ${ }^{2}$ Department of Clinics, Madras Veterinary College, Chennai, Tamil Nadu, India \\ ${ }^{3}$ Mobile Veterinary Officer, TANUVAS, Tamil Nadu, India
}

*Corresponding author

\begin{tabular}{|c|c|c|}
\hline & \multicolumn{2}{|l|}{ A B S T R A C T } \\
\hline $\begin{array}{l}\text { Ke y w or d s } \\
\text { Progesterone, } \\
\text { Prostaglandin, } \\
\text { PMSG, Follicle }\end{array}$ & \multirow{3}{*}{\multicolumn{2}{|c|}{$\begin{array}{l}\text { The present study was aimed to evaluate the efficacy of estrus response in synchronized } \\
\text { does using intravaginal sponges containing } 350 \mathrm{mg} \text { progesterone (AVIKESIL-S) in situ for } \\
11 \text { days, } 125 \mu \mathrm{g} \text { Cloprostenol, on day } 10 \text { and PMSG at two does of } 200 \mathrm{IU} \text { (Group I) or } \\
400 \mathrm{IU} \text { (Group II) on day } 11 \text { at the time of sponge removal, in non-descript does under } \\
\text { field conditions. The percentage of estrous response and duration of estrus were observed } \\
\text { to be } 70,100 \text { and } 100 ; 40.93 \pm 1.49,42.20 \pm 1.32 \text { and } 49.50 \pm 0.94 \text { in control, Group I and } \\
\text { Group II respectively. Pregnancy verification was done } 40 \text { to } 45 \text { days post mating by } \\
\text { ultrasound examination and the conception rate in control, Group I and Group II was } \\
52.40,63.33 \text { and } 66.67 \text { respectively. Follicular study, pre and post treatment of PMSG in } \\
\text { the treatment groups indicated an increase in daily growth rate of follicles from } 0.05 \text { to } \\
0.09 \mathrm{~mm} \text { with the increase in dose of PMSG from } 100 \mathrm{IU} \text { to } 400 \mathrm{IU} \text {. }\end{array}$}} \\
\hline Article Info & & \\
\hline $\begin{array}{l}\text { Accepted: } \\
\text { 17 July } 2018 \\
\text { Available Online: } \\
10 \text { August } 2018 \\
\end{array}$ & & \\
\hline \multicolumn{3}{|l|}{ Introduction } \\
\hline \multicolumn{3}{|c|}{$\begin{array}{l}\text { Reproductive performance is one of the } \\
\text { important economic traits in goats. }\end{array}$} \\
\hline \multicolumn{2}{|c|}{$\begin{array}{l}\text { Higher pregnancy rates, birth weight and rapid } \\
\text { recovery of doe's weight after parturition are } \\
\text { important reproductive characteristics } \\
\text { deciding the benefits of goat rearing (Gangyi } \\
\text { et al., 1992). }\end{array}$} & $\begin{array}{l}\text { and prostaglandins. Progestagens are } \\
\text { administered by vaginal devices for short or } \\
\text { long duration, with better fertility (Gordon, } \\
\text { 1997). }\end{array}$ \\
\hline \multicolumn{2}{|c|}{$\begin{array}{l}\text { Estrus synchronization enables large number } \\
\text { of females to be presented for breeding within } \\
\text { a short chosen period of time so as to assure } \\
\text { kidding during optimum time of the year with }\end{array}$} & $\begin{array}{l}\text { The present work was conducted to evaluate } \\
\text { the dose of PMSG used in combination with } \\
\text { progesterone and prostaglandin for control of } \\
\text { reproductive cycles in non-descript does under } \\
\text { field conditions. }\end{array}$ \\
\hline
\end{tabular}




\section{Materials and Methods}

\section{Location of study}

The present study was carried out at farmers' flocks in Kanchipuram district of the Tamil Nadu State of India. These villages are located in the semi-arid region of the country situated at $12050^{\prime}$ ' North Latitude and 790 - 42' east longitude with an average elevation of $275^{\prime}$ (83-82m) M.S.L. The temperature throughout the year is high; reaching a maximum average of $37.50^{\circ} \mathrm{C}$ in the month of April to July and recording of minimum average of $\quad 20.50^{\circ} \mathrm{C}$ temperatures during the months of December to February. Average annual rainfall of the Local Planning Area is 40 " or 1125 m.m.

\section{Selection of animals}

Non-descript does were screened for reproductive tract abnormalities and pregnancy by using Ultrasound (Sonoscape S2 V) with $7.5 \mathrm{MHz}$ transrectal probe and ninety does in their first to fourth parity were selected for this study. The selected does were dewormed with fenbendazole at the dose rate of $10 \mathrm{mg} / \mathrm{kg}$ body weight and supplemented with mineral mixture $10 \mathrm{~g} /$ day/animal. The selected does were assigned to control and treatment group irrespective of the stage of the cycle.

\section{Experimental design}

Thirty selected does kept as control, were observed for the onset of natural estrus signs. In group I, the selected does $(n=30)$ were treated with progesterone impregnated synthetic vaginal sponges (AVIKESIL-S), placed in the vagina for 11 days with an intramuscular injection of Cloprostenol sodium (Inj. Pragma, Intas pharmaceuticals) at $125 \mu \mathrm{g} / \mathrm{doe}$ on day 10 and 100 I.U. of PMSG (Inj.Folligon, Intervet) intramuscularly on day 11, at the time of sponge removal. In group II, the does $(n=30)$ were treated with progesterone sponges for 11 days with an intramuscular injection of Cloprostenol sodium at $125 \mu \mathrm{g} / \mathrm{doe}$ on day 10 and $400 \mathrm{I} . \mathrm{U}$. of PMSG intramuscularly on day 11, at the time of sponge removal.

All the treated does were observed for the onset of estrus signs. All the treated does were examined for ovarian status using B-mode ultrasound equipment using a $7.5 \mathrm{MHz}$ linear probe (Sonoscape S2 V) transrectally and follicular diameters were measured from day 10 to day 13 .

\section{Statistical analysis}

All the collected data were analyzed statistically by the method described by Snedecor and Cochran (1989). Data pertaining to estrus response was calculated by using one-way analysis of variance and conception rate was evaluated by Chi-square test.

\section{Results and Discussion}

Estrus responses obtained after different treatments are given in Table 1. Estrus response was observed in $60 \%$ in the control group whereas $100 \%$ response was obtained in group II and group III. The estrus response was significantly $(\mathrm{P}<0.01)$ higher in groups treated with PMSG (groups I and II) when compared to control.

The mean $( \pm$ SE) follicular diameter on day 10 was found to be $0.28^{\mathrm{ab}} \pm 0.06$ and $0.22^{\mathrm{a}} \pm 0.07$ $\mathrm{mm}$ in group I and II respectively and the corresponding values on day 13 was $0.41^{\mathrm{bc}} \pm$ 0.03 and $0.50^{c} \pm 0.03 \mathrm{~mm}$. The growth rate of follicle per day was $0.50 \mathrm{~mm}$ in group I and $0.90 \mathrm{~mm}$ in group II (Table 2).

Duration of estrus was significantly $(\mathrm{P}<0.01)$ higher in group I and group when compared to control group (Table 1). However there was 
no significant difference between control and does in group I. Conception rate in control, group I and group II was 52.40, 63.33 and 66.67 per cent respectively.

Estrus response was observed to be 100 per cent in group II and group III. This finding is in line with the reports of Das et al., (1997), Shawki et al., (2000), Hashemi et al., (2006), Luther et al., (2007) and Ustuner et al., (2007) who also reported estrus response of 100 per cent, using progesterone intravaginal sponges and PMSG treatment. Thus the addition of PMSG induced estrum in all the does in group II and group III, irrespective or the dose levels used. However it was higher than $96.7 \%$ (400 IU PMSG) and 76. 7\% (200 IU PMSG) obtained by Dias et al., (2001) and $88.9 \%$ obtained by Dogan and Nur (2006).

In all the treated does, the interval from withdrawal of vaginal sponges to onset of estrus was recorded in the range of 36 to 42 hours. No variation in onset of estrum was observed between group I and group II in the present study. The results concurred with the findings of Selvaraju (1994) and Senthilkumar et al., (2016) using progesterone and PMSG combination however longer estrus onset (65.4 $\pm 24.0 \mathrm{~h}$ ) was observed by Kausar et al., (2009) using MAP sponges alone for a period of 17 days.

The diameter of the ovulatory follicle at the time of device withdrawal was similar among groups ( $\geq 3 \mathrm{~mm}$ ), but its development was influenced by the administration of PMSG in comparison with the control goats. More number of follicles of diameter $>4 \mathrm{~mm}$ were recruited (Figure 1 and 2) with the high dose of PMSG (Figure 3) and the average growth rate of follicles were found to be increased from 0.5 to $0.9 \mathrm{~mm}$ per day (Table 2) when the dose of PMSG was increased from $100 \mathrm{IU}$ to $400 \mathrm{IU}$. This could be due to the long biological half-life of PMSG leads to a continuous recruitment and development of follicles (Armstrong et al., 1983).

Table.1 Estrus responses in the treated and control groups

\begin{tabular}{|c|c|c|c|}
\hline & \multicolumn{3}{|c|}{ Treatment Groups } \\
\hline Parameters & Control & $\begin{array}{c}\text { Group I } \\
(\text { P4+ PG + 100 IU } \\
\text { PMSG })\end{array}$ & $\begin{array}{c}\text { Group II } \\
(\text { P4+ PG + 400 IU } \\
\text { PMSG) }\end{array}$ \\
\hline No. of does treated & 30 & 30 & 30 \\
\hline Estrus response (\%) & $\begin{array}{l}70.0^{\mathrm{a}} \\
(21)\end{array}$ & $\begin{array}{l}100^{b} \\
(30)\end{array}$ & $\begin{array}{l}100^{b} \\
(30)\end{array}$ \\
\hline $\begin{array}{c}\text { Mean } \pm \text { SE duration } \\
\text { of estrus }(h)\end{array}$ & $40.93^{\mathrm{a}} \pm 1.49$ & $42.20^{\mathrm{a}} \pm 1.32$ & $49.50^{b} \pm 0.94$ \\
\hline Conception rate $(\%)$ & $\begin{array}{c}52.40 \\
(11)\end{array}$ & $\begin{array}{r}63.33 \\
(19)\end{array}$ & $\begin{array}{c}66.67 \\
(20)\end{array}$ \\
\hline
\end{tabular}


Table.2 Assessment of follicular population in the treatment groups

\begin{tabular}{|c|c|c|}
\hline & Group I & Group II \\
\hline $\begin{array}{c}\text { Mean( } \pm \text { SE) follicular diameter } \\
\text { on Day 10 (mm) }\end{array}$ & $0.28^{\mathrm{ab}} \pm 0.06$ & $0.22^{\mathrm{a}} \pm 0.07$ \\
\hline \begin{tabular}{c} 
Mean( $\begin{array}{c}\text { SE) follicular diameter } \\
\text { on Day 13 }(\mathrm{mm})\end{array}$ \\
\hline $\begin{array}{c}\text { Growth rate of follicle per day } \\
(\mathrm{mm})\end{array}$
\end{tabular} & $0.41^{\mathrm{bc}} \pm 0.03$ & $0.50^{\mathrm{c}} \pm 0.03$ \\
\hline
\end{tabular}

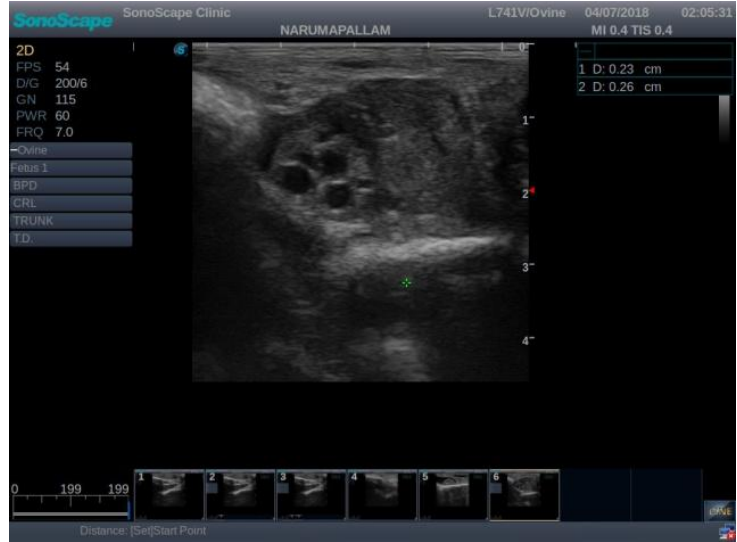

Fig.1 Ultrasound image of ovary (day13) in Group I

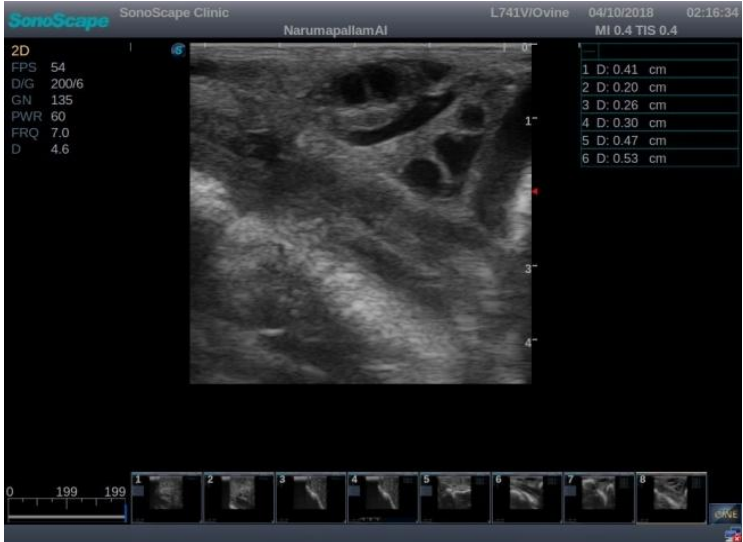

Fig.2 Ultrasound image of ovary (day 13) in Group II

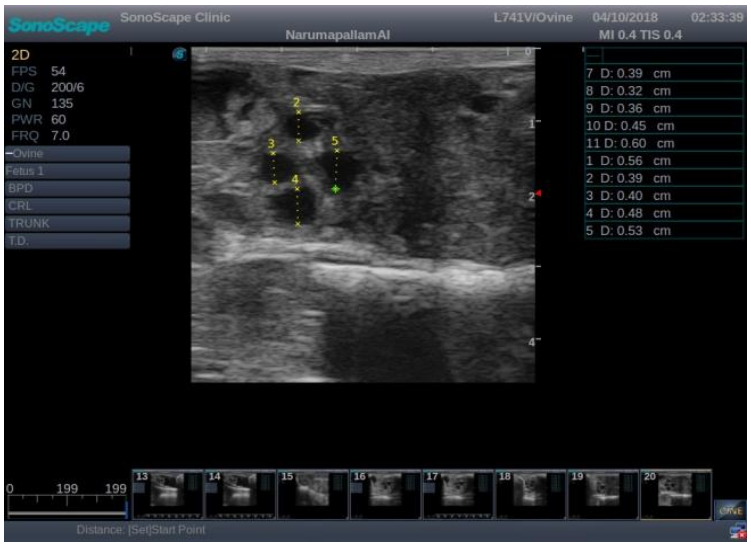

Fig.3 Measurement of follicular diameter

In the present study the duration of estrus was significantly $(\mathrm{P}<0.05)$ higher in the does treated with 400 IU (group II) The addition of PMSG of either dose levels prolonged the estrus duration in group I and group II when compared to control does (Table 1). The duration of estrus was also prolonged with the increased dosage of PMSG (400 IU) in the progesterone primed does. The mean estrus duration of treated does in the present study are higher the range of 6 to 42 hours reported by Das et al., (2000), in Bharat Merino ewes synchronized with intravaginal $(350 \mathrm{mg})$ progesterone sponges; $52 \pm 7.8 \mathrm{~h}$ in Nubian goats reported by Ahmed et al., (1998) in does synchronised with intravaginal sponges impregnated with progesterone $(40 \mathrm{mg})$ inserted for a 16-day period plus an intramuscular injection of 300 IU PMSG two days before sponge removal. The longer 
duration of estrus observed in group II compared to Group I and control are attributed due the higher dose of PMSG treatment which results in maximal circulating oestradiol values (Rensis and López-Gatius, 2014).

Among the does bred 11(52.40\%), 19 $(63.33 \%)$ and $20(66.67 \%)$ does conceived in control, group I and group II respectively. Though there was an increase in the conception rate in the treatment groups compared to the control, it was not statistically significant. The percentage conception rate was similar to that of Vinoles et al., (2001) who recorded 67.0\%, in ewes synchronized with MAP intravaginal sponge in situ for 12 days followed by eCG injection and also similar to the $60.0 \%$ conception rate reported by Martemucci and Alessandro (2010) in ewes synchronized with $40 \mathrm{mg}$ of FGA intravaginal sponges in situ for 14 days followed by $400 \mathrm{IU}$ of eCG at the time of sponge withdrawal. However Dogan et al., (2018) reported a lower conception rate (27.8\%) using norgestomet ear implants plus an intramuscular injection of $500 \mathrm{IU}$ of equine chorionic gonadotropin (eCG) and $125 \mu \mathrm{g}$ cloprostenol (PGF2 $\alpha), \quad 48 \mathrm{~h}$ prior to progestagen removal.

The increased estrus response and improved conception rate was found to higher in does treated with 400 IU PMSG. PMSG has both FSH and LH - like activity, thereby improves the development and the ovulation rate of the dominant pre-ovulatory follicle. Thus the quality of the ensuing CL is improved leading to increased progesterone secretion with a positive effect on embryo development and survival (Rensis and López-Gatius, 2014).

In conclusion, the results of the present study suggest that progesterone treatment in combination with PMSG improves the estrus response and conception rate when compared to untreated control does. This indicates the administration of 400 I.U. of PMSG augments the effect of natural progesterone for synchronization of estrus in non-descript local does.

\section{Acknowledgment}

The authors are greatly thankful to National Agriculture Development Programme (NADP) Animal Mobile Medical Ambulance scheme for providing necessary funding for the research.

\section{References}

Ahmed, M.M., S.E. Makawi and A.S. Jubara, 1998. Synchronization of oestrus in Nubian goats. Small Ruminant Research, 30 (2): 113-120.

Armstrong, D.T., A.P. Pfitzner, G.M. Warnes, M.M. Ralph and R.F. Seamark, 1983. Endocrine responses of goats after induction of superovulation with PMSG and FSH. Journal of Reproduction and Infertility, 67 (2): 395-401.

Chaudhari, A., Haque, N., Jamnesha, N., Bhalakiya, N., Patel, G., Madhavatar, M., Patel, D. and Patel, P., Synchronization of Estrus: A Reproductive Management Tool in Veterinary Practice.

Das, G.K., S.M.K Naqvi, R. Gulyani, S.R. Pareek and J.P. Mittal, 1999. Effect of progesterone and PMSG treatments on estrus response and fertility in acycling sheep during summer. Indian. J. Anim Sci., 69: 178-179.

Das, G.K., S.M.K. Naqvi, R. Gulyani, S.R. Pareek and J.P. Mittal, 2000. Effect of two doses of progesterone on estrus response and fertility in acycling crossbred Bharat Merino ewes in a semi-arid tropical environment. Small Ruminant Research, 37 (1-2): 159-163. 
De Rensis, F. and F. López-Gatius (2014). Use of equine chorionic gonadotropin to control reproduction of the dairy cow: a review. Reproduction in Domestic Animals, 49 (2): 177-182.

De, K., D. Kumar, D. Sethi, R. Gulyani and S.M.K. Naqvi, 2015. Estrus synchronization and fixed-time artificial insemination in sheep under field conditions of a semi-arid tropical region. Tropical Animal

Health and Production. 47 (2): 469-472.

Dogan L. and Nur Z. (2006). Different estrous induction methods during the nonbreeding season in Kivircik ewes. Journal of Veterinary Medicine. 51, 133- 138.

Dogan, I., Z. Nur, and B. Kilinc, 2018. Different estrus induction protocols and fixed time artificial insemination during the anoestrous period in non-lactating Kivircik ewes. Journal of the Hellenic Veterinary Medical Society 69 (1): 801 808.

Gordon, I., 1997. Controlled reproduction in Sheep and Goats. Cab International

Hashemi, M., M. Safdarian and M. Kafi, 2006. Estrous response to synchronization of estrus using different progesterone treatments outside the natural breeding season in ewes. Small Ruminant Research, 65 (3): 279-283.

Kausar, R., Khanum, S.A., Hussain, M. and Shah, M.S., 2009. Estrus synchronization with medroxyprogesterone acetate impregnated sponges in goats (Capra hircus). Pakistan Veterinary Journal, 29 (1).
Luther, J.S., A.T. Grazul-Bilska, J.D. Kirsch, R.M. Weigl, K.C. Kraft, C. Navanukraw, D. Pant, L.P. Reynolds and D.A. Redmer, 2007. The effect of $\mathrm{GnRH}$, eCG and progestin type on estrous synchronization following laparoscopic AI in ewes. Small Ruminant Research, 72 (2-3): 227-231.

Martemucci, G. and A.G, D'Alessandro, 2010. Estrous and fertility responses of dairy ewes synchronized with combined short term GnRH, PGF2 $\alpha$ and estradiol benzoate treatments. Small Ruminant Research., 93 (1): 41-47.

Selvaraju, M., 1994. Studies on estrus sunchronization on Tellichery goats. M.V.Sc. Thesis. Tamil Nadu Veterinary and Animal Sciences University, Chennai.

Senthilkumar, K., Selvaraju, M., Napolean, R.E., Doraisamy, K.A. and Mohan, B., 2016. Pattern of Oestrus and Fertility Rate Following Synchronization of Ovulation in Tellicherry Goats.

Snedecor, G.W. and W.G. Cochran, 1989. Statistical Methods. Iowa State University Press, Ames, IA, 237-252.

Ustuner, B., U. Gunay, Z. Nur and H. Ustuner, 2007. Effect of long and shortterm progestagen treatments combined with PMSG on oestrus synchronization and fertility in Awassi ewes during the breeding season. Acta Veterinaria Brno., 76: 391-397.

Vinoles, C., Forsberg, M., Banchero, G., Rubianes, E., 2001. Effect of long-term progestagen treatment on follicular development and pregnancy rate in cyclic ewes. Theriogenology 55, 9931004.

\section{How to cite this article:}

Kavitha, K., Cecilia Joseph, T. Sarath and Pugazharasi, C. 2018. Effect of Different Doses of PMSG for Synchronisation of Estrus in Progesterone Primed Goats. Int.J.Curr.Microbiol.App.Sci. 7(08): 3066-3071. doi: https://doi.org/10.20546/ijcmas.2018.708.326 